Journal of the Egyptian Society of Parasitology, Vol.43, No.3, December 2013

J. Egypt. Soc. Parasitol., 43(3), 2013: 569 - 576

\title{
DETERMINATION OF SEROPOSITIVITY FOR TOXOPLASMA GONDII \\ IN SHEEP, GOATS AND CAMELS SLAUGHTERED FOR FOOD AND HUMAN CONSUMPTIONS IN RIYADH MUNICIPAL ABATTOIRS, SAUDI ARABIA
}

\section{By}

ABDULLAH D. ALANAZI

Department of Biological Sciences, Faculty of Science and Humanities, Shaqra University, P.O. Box 1040 Ad-Dawadimi 11911, Saudi Arabia, E mail: aalanazi@su.edu.sa.

\begin{abstract}
Serum samples from 891 sheep, 555 goats and 182 camels slaughtered for food and human consumption from three main municipal abattoirs in Riyadh City, Saudi Arabia were tested for antibodies to Toxoplasma gondii by the an indirect fluorescent antibody test (IFAT). Antibodies to $T$. gondii were found in $36.4 \%(325 / 891)$ sheep and $35.3 \%(196 / 555)$ goats and $23.6 \%(43 / 182)$ camels, at a dilution of $1: 32$ or more for goats and sheep and 1:64 or more for camels. There was no significant difference in infection between sheep, goats and camels in Riyadh City $(P>0.05)$. The results indicated that $T$. gondii antibodies were wide-spread in the animal populations for human consumption and welfare, and that toxoplasmosis is a widely spread zoonotic infection in Riyadh City.
\end{abstract}

Keywords: Saudi Arabia, Riyadh City, Toxoplasma gondii, Sheep, Goats, Camels, zoonosis, IFAT.

\begin{tabular}{|c|c|}
\hline & \\
\hline $\begin{array}{l}\text { Toxoplasmosis is an increasing zo- } \\
\text { onosis of worldwide distribution con- } \\
\text { cern hazards in both human health and } \\
\text { veterinary medicine. The disease is } \\
\text { caused by an obligate intracellular pro- } \\
\text { tozoan parasite called "Toxoplasma } \\
\text { gondii" (Halonen and Weiss, 2013). } \\
\text { Whilst the sexual life cycle of the para- } \\
\text { site is confined to cats (the definitive } \\
\text { host), the asexual cycle occurs in many } \\
\text { warm blooded animals (Dubey and } \\
\text { Beattie, 1988). The most common } \\
\text { sources of human infection are inges- } \\
\text { tion of tissue cysts in raw meat or of } \\
\text { food or water contaminated with oo- }\end{array}$ & $\begin{array}{l}\text { transmission (Dubey and Joens, } 2008 \text {; } \\
\text { Dubey, 2010). T. gondii infections in } \\
\text { the domestic animals are subclinical. } \\
\text { Clinical signs, when present, are gen- } \\
\text { erally vague and nonspecific and may } \\
\text { include a period of fever, anorexia, } \\
\text { respiratory distress and sometimes di- } \\
\text { arrhea, however, the disease is major } \\
\text { cause of abortion and perinatal mortali- } \\
\text { ty in the sheep and goats (Buxton and } \\
\text { Brebner, 1998; Hill and Dubey, 2013). } \\
\text { In Saudi Arabia, the sheep, goats and } \\
\text { camels populations after the Ministry } \\
\text { of Agriculture (2011) were more than } \\
8.5 \text { million. Besides more than } 5 \text { mil- }\end{array}$ \\
\hline
\end{tabular}


lion are imported of live sheep, goats and camels annually from several countries such as Sudan, Ethiopia, Brazil, Argentina, Romania and Turkey for meat, and animal products. In the last two or three years, there have been several storms of abortions and stillbirths in commercial farms in Riyadh area consistent with toxoplasmosis (Hussein et al, 2011).

The aim of this work was to determine $T$. gondii antibodies in edible animals from three different zones in Riyadh City, from September 2012 to June 2013 using indirect fluorescent antibody test (IFAT).

\section{Materials and Methods}

Riyadh City is the Capital with geographical position at latitude $34^{\circ}-38^{\circ}$ north and longitude $43^{\circ}-46^{\circ}$ east, about $3,024 \mathrm{~km}^{2}$ and inhibited by approximately five million persons. Riyadh region has very hot summer up to $50^{\circ} \mathrm{C}$ or more with an average temperature of $45^{\circ} \mathrm{C}$. Winter is cold with windy nights. The overall climate is arid, receiving very little rainfall of $21.4 \mathrm{~mm}$ with relative humidity ranging from $10 \%$ to $47 \%$ throughout the year. Riyadh region is also known to have many dust storms. Blood samples were withdrawn from jugular vein of sheep, goats and camels from the three governmental slaughter-houses in Southern, Western and Eastern of Riyadh city. A total of 1628 animals (891 sheep, 555 goats and 182 camels) were collected (Tab. 1). The blood samples were immediately transported to Parasitology Research Laboratory, Faculty of Science and Humanities, Shaqra University. Sera were separated by centrifuged at $4000 \mathrm{rpm}$ for $10 \mathrm{~min}$, and stored in a deep freeze at $-20^{\circ} \mathrm{C}$ until assayed for $T$. gondii antibodies.

Sera thawed at $35^{\circ} \mathrm{C}$ immediately before testing for antibodies to $T$. gondii by IFAT (Voller and O'Neill, 1971). Positive serum samples showing a titer of $1: 32$ were further diluted to determine the end point. Titers of 1:32 or above were considered to be positive for sheep and goats and 1:64 or above for camels.

Statistical analysis: Data were computerized and statistically analysis using a Chi square test (SPSS Inc., Chicago, Illinois). $P$-value $<0.05$ was considered significant (Armitage, 1983).

\section{Results}

The seroprevalence of $T$. gondii antibodies in sheep, goats and camels within the Riyadh city was found to be $36.4 \%$, 35.3\% \& $23.6 \%$, respectively. This difference was statistically not significant according to the chi-square test $(P>0.05)$. No significant differences were indicated in seroprevalence for sheep, goats and camels from different areas of Riyadh city $(P>0.05)$.

The details are shown in table (2).

Table 1: Samples collected from three municipal abattoirs in Riyadh City.

\begin{tabular}{|l|c|c|c|c|}
\hline Animal & $\begin{array}{c}\text { South } \\
\text { (Al-Azizia abattoir) }\end{array}$ & $\begin{array}{c}\text { East } \\
\text { (Al-Sa'adah abattoir) }\end{array}$ & $\begin{array}{c}\text { West } \\
\text { (Abattoir) }\end{array}$ & Total \\
\hline Sheep & 313 & 287 & 291 & 891 \\
\hline Goat & 201 & 198 & 156 & 555 \\
\hline Camel & 65 & 71 & 46 & 182 \\
\hline Total & 579 & 556 & 493 & 1628 \\
\hline
\end{tabular}


Table 2: IFAT-T. gondii antibodies in sheep, goats and camels in Riyadh City.

\begin{tabular}{|r|c|c|c|c|c|c|}
\hline \multirow{2}{*}{$\begin{array}{c}\text { Abattoir } \\
\text { location }\end{array}$} & \multicolumn{2}{|c|}{ Sheep } & \multicolumn{2}{c|}{ Goat } & \multicolumn{2}{c|}{ Camel } \\
\cline { 2 - 7 } & No. examined & No. +ve (\%) & No. examined & No. +ve (\%) & No. examined & No. +ve (\%) \\
\hline South & 313 & $113(36 \%)$ & 201 & $86(42.8 \%)$ & 65 & $13(20 \%)$ \\
\hline East & 287 & $88(30.6 \%)$ & 198 & $63(31.8 \%)$ & 71 & $19(26.7 \%)$ \\
\hline West & 291 & $124(42.6 \%)$ & 156 & $47(30.1 \%)$ & 46 & $11(23.9 \%)$ \\
\hline Total & 891 & $325(36.4 \%)$ & 555 & $196(35.3 \%)$ & 182 & $43(23.6 \%)$ \\
\hline
\end{tabular}

\section{Discussion}

Three infectious stages of $T$. gondii were identified; tachyzoites (groups or clones), bradyzoites (tissue cysts) and sporozoites (oocysts) linked in a complex life cycle (Elsheikha et al, 2008).

The present results can be compared with previous studies from different provinces of Saudi Arabia. For example, the rate of $T$. gondii infection in Jeddah Municipal abattoir western of Saudi Arabia using IHAT was found to be $39 \%$ in sheep and $28 \%$ in goats (Amin and Morsy, 1997) and 52.2\% in sheep and $51.7 \%$ in goats from Tabouk official abattoir north of Saudi Arabia by IFAT (Sanad and Ghabban, 2007). Al-Mohammed (2011) reported that ELISA-antibodies against $T$. gondii were $22 \%$ in sheep and $12 \%$ in goats from Al-Ahasa District. The antibodies against $T$. gondii in camels ranged between $2 \%$ to $16 \%$ (Hussein et al, 1988; El-Metenawy, 2000; Al-Mohammed, 2011; Alanazi, 2011).

In the present study, IFAT was used due to highest sensitivity and specificity. Sanad and Ghabban (2007) reported $100 \%$ and $96.7 \%$, specificity $97.1 \%$ and $96.1 \%$ and diagnostic accuracy $98.5 \%$ and $96.9 \%$ in sheep and goats respectively, as compared with LAT and IHAT. Mendonça et al. (2013) stated that Toxoplasma-IFAT-IgG with a a cutoff point of 1:64 proved highly specific and sensitive for sheep.

T. gondii infection in slaughter sheep and goats varied in many countries, the previous studies indicates that prevalence of infection among sheep was higher than that for goats (Hossain et al, 1987; Chantal et al, 1994; Zaki, 1995; Mirdha et al, 1995: Skjerve et al, 1996; Hashemi-Fresharki, 1996; Iskandar, 1998; van der Puije et al, 2000; Khalil and Elraya, 2011). These variations of $T$. gondii infection among sheep and goats may be due to the samples size of different studies or to the different serological methods used, also may be due to variations in sheep and goats feeding different methods of management and according to species immunity.

In the present study, the seropositivity of $T$. gondii in camel was not so high when compared with results from more or less similar environmental conditions (Rifaat et al, 1979). Abroad, the prevalence was $17.4 \%$ of Egyptian camels (Hilali et al, 1998). Khalil and Elraya (2011) found $20 \%$ of slaughter camels from Khartoum State, Sudan.

Nevertheless, the prevalence of $T$. gondii infection in the present study was lower than that $(48 \%)$ reported 
from Iraqi camels (Saleem and Fatohi, 1993).

In Saudi Arabia, particularly in the rural areas people are daily in direct contact with their livestock. No doubt, one of the major consequences of pregnant women becoming infected by $T$. gondii is vertical transmission to the fetus (Elsheikha and Morsy, 2009). The present results might give an explanation of the high prevalence of human infection that ranged between $21 \%$ and $49.3 \%$. Saudi pregnant woman with miscarriage or congenital toxoplasmosis were reported by so many authors as (Shoura et al, 1073; Morsy and E1 Dasouki, 1973; 1974; 1977; Kandil et al, 1980; El-Hady, 1991; Abdalla et al, 1994; Al Ghazi et al, 2004; Alharthi et al, 2006; Al-Harthi et al, 2006; Tonkal, 2008; Mohammed et al, 2011) and even among Saudi blood donors (Sarwat et al, 1973; Al-Amari, 1994; Yanaza and Kumari, 1994; Makki and Abdel-Tawab, 2010). Moreover, Tabbara (1990) reported ocular toxoplasmosis, which can be congenital or acquired with a variety of clinical manifestations that ranges from a subclinical course to a generalized infection with fatal outcome. On the other hand, Soliman et al. (1985) reported that the only avaiable drug at that time pyrimethamine had toxic effects of in albino rats.

Apart from man, El-Sebai (1991) in Qassem detected anti-Toxoplasma antibodies among wild rodents. Morsy et al. (1994) reported IHAT-antibodies against Toxoplasma in sera of different of rodents' species. Positivity ranged between $12.5 \%$ in the house mouse
(Mus musculus) and $41.7 \%$ in the Norwegian rodent (Rattus norvegicus). The overall rate of infection was $35.6 \%$. Al Dakhil and Morsy (1996) in the Eastern Region of the Kingdom 4/6 grey mongoose were IHAT-positive for $T$. gondii and parasites were successfully isolated by mice I.P. inoculation from one of them. Morsy et al. (2001) in Najran District examined 25 Meriones rex or king jird reported Xeno-psylla astia, Ctenocephalides arabicus, Ornithonyssus bacoti and tick nymphs with indices of 0.6, 1.6, 0.64 and 0.24 respectively. The ectoparasites were more on females than on males with indices of 3.8 and 2.0 respectively. The IHAT-anti Toxoplsama and anti-Leishmania antibodies showed positive reactions in $5(20.0 \%)$ and $2(8.0 \%)$ jirds respectively. However, neither the skin lesion nor protozoa parasites were detected in tissue smears of liver and spleen. Even more anti-Toxoplasma antibodies were reported in lizards (Al Sadoon and El Bahrawy, 1998).

Apart from meat, Chiari and Neves (1984) reported acute toxoplasmosis in three family members due to drinking unpasteurized goat's milk from one of five goats. Dogs in the same house showed no symptoms of toxoplasmosis but low antibody titers. Turner and Savya (1990) reported $T$. gondii in an equine placenta.

Hiramoto et al. (2001) found that the infectivity of cysts of the ME-49 strain of $T$. gondii was maintained in milk even after storage for 20 days at refrigerators. Cysts also survived the process of homemade cheese and storage for up to 10 days in the same conditions. They 
added that milk and dairy products proved an important source in human contamination, reinforcing importance of pasteurization before processing. Santos et al. (2009) among 2000 female dairy cattle in 50 farms found positive IFAT in $1420(71 \%)$ cattle, $54(88.5 \%)$ dogs and 113 (97.4\%) far-mers.

Moreover, Haridy et al. (2010) reported ELISA- $T$. gondii positive in the milk from 7/15 pregnant females donkeys. They added that donkey's and goat's milks have been used as good alternatives to human and bovine milk in various clinical conditions as allergy, atopy and inflammatory diseases since these type of milks possess immune-modulating capacities and release nitric oxide, a potent vasodilator endowed with antiatherogenic properties. Equine meat and milk is not accepted many countries, but accepted in others.

\section{Conclusion}

Toxoplasmosis is a common infection of man and animals with worldwide zoological and geographical distribution including Saudi Arabia. The outcome results showed that the $T$. gondii specific antibodies against sheep and goats was high and low for camels, and consequent risk of acquiring toxoplasmosis by consumption of sheep and goat meat and milk more than camels. Besides, acquired human toxoplasmosis is due to the contaminated sources such as fresh milk, home prepared cheese/sausage.

So, the health authorities must consider the integrated strategies, including efficient management measures for prevention and control $T$. gondii infection in these edible animals.

\section{Acknowledgements}

This project was kindly supported by Shaqra University, Deanship of Scientific Research.

The author would like to thank the Staff Members of the Biological Sciences Department, Faculty of Science and Humanities, Shaqra University for kind technical support.

\section{References}

Abdalla, KF, EI Fakahany, AF, Arafa, MAS, Salama, MMI, Morsy, TA, 1994: Congenital toxoplasmosis in premature in Saudi Arabia. J. Egypt. Soc. Parasitol. 24, 3:643-8.

Al Amari, OM, 1994: Prevalence of antibodies to Toxoplasma gondii among blood donors in Abha, Asir Region, southwestern Saudi Arabia. J. Egypt. Pub. Hlth. Assoc. 69:77-88.

Al Dakhil, MA, Morsy, TA, 1996: Natural toxoplasma infection sought in the Indian grey mongoose $(H$. edwar$d s i$, Greffroy, 1818) trapped in the eastern region, Saudi Arabia. J. Egypt. Soc. Parasitol. 26, 3:645-52.

Al Ghazi, HO, Telmesani, AM, Mahomed, MF, 2002: Torch age-agents in pregnant Saudi women. Med. Princ. Pract. 11, 4:180-90.

Al-Harthi, SA, Jamjoom, MB, Ghazi, HO, 2006: Seroprevalence of Toxoplasma gondii among pregnant women in Makkeh, Saudi Arabia Umm AlQura University. J. Sci. Med. Engne. 18, 2:217-27.

Al Sadoon, M, El Bahrawy, A, 1998: Blood parasites of five species of lizza- 
rds trapped in Abha province, Saudi Arabia. J. Egypt. Soc. Parasitol. 28, 3: 883-905.

Alanazi, AD, 2011: Seroprevalence of Neospora caninum and Toxoplasma gondii antibodies in sera from camels (Camelus dromedarius) in Riyadh province, Saudi Arabia. J. Egypt. Soc. Parasitol. 41, 2:245-50.

Amin, AM, Morsy, TA, 1997: AntiToxoplasma antibodies in butchered and slaughtered sheep and goats in Jeddah Municipal abattoir, Saudi Arabia. J. Egypt. Soc. Parasitol. 17:913-8.

Armitage, P, 1983: Statistical Methods in Medical Research. Blackwell Scientific Publications, Oxford, London.

Chantal J, Dorchies P, Legueno B, 1994: Enquete surcertaines zoonoses en Re'publique de Djibouti I. chez les uminants a' l'abattoir de Djibouti. Rev. Me'd. Ve't. 145:633-40.

Chiari, CA, Neves, DP, 1984: Human toxoplasmosis acquired by ingestion of goat's milk. Mem. Inst. Oswaldo Cruz, 79, 3:337-40.

Dubey JP, 2010: Toxoplasmosis of Animals and Humans. $2^{\text {nd }}$ edition. Boca Raton, Florida: CRC Press.

Dubey, JP, Beattie, CP, 1988: Toxoplasmosis of Animals and Man. CRC Press, Boca Raton, Florida.

Dubey, JP, Joens, JL, 2008: Invited Review Toxoplasma gondii infection in humans and animals in the United States. Int. J. Parasitol. 38:1257-78.

El-Hady, MM, 1991: Toxoplasmosis among pregnant mothers in Abha, Saudi Arabia. J. Egypt. Soc. Parasitol. 21, 3:811-5.
El-Metenawy TM, 2000: Sero-prevalence of Toxoplasma gondii antibodies among domesticated ruminants at AlQassim Region, Saudi Arabia. Dtsch. Tierarztl. Wochenschr. 107:32-3.

El-Sebai, MM, 1991: Study on toxoplasmosis in Qassem, Saudi Arabia. J. Egypt. Soc. Parasitol. 21, 1:273-5.

Elsheikha, HM, Morsy, TA, 2009: Role of immune response in $T$. gondii tachyzoite-bradyzoite stage interconversion: A Janus in determining disease outcome (short communication). J. Egypt. Soc. Parasitol. 39, 2: 595-8.

Elsheikha, H, Hafez, AO. Zaalouk, T Kh, El Shazly, AM, Khalil, HM, Morsy, TA, 2008: Phylogenetic evidence for recombination in sag5 locus in Toxoplasma gondii. J. Egypt. Soc. Parasitol. 38, 2:371-384.

Halonen, SK, Weiss, LM, 2013: Toxoplasmosis. Handb. Clin. Neurol. 114: 125-45.

\section{Haridy, FM, Saleh, NMK, Khalil, H} HM, Morsy, TA, 2010: Anti-Toxoplasma gondii antibodies in working donkeys and donkey's milk in Greater Cairo, Egypt. J. Egypt. Soc. Parasitol. 40, 2:459-64.

Hashemi-fesharki, R, 1996: Seroprevalence of Toxoplasma gondii in cattle, sheep and goats in Iran. Vet. Parasitol. 61:1-3.

Hilali, M, Romand, S, Thulliez, P, Kwok, OC, Dubey, JP, 1998: Prevalence of Neospora caninum and Toxoplasma gondii antibodies in serum from camels from Egypt. Vet. Parasitol. 75, 2/3:269-71.

Hill, DE, Dubey, JP, 2013: Invited Review Toxoplasma gondii prevalence 
in farm animals in the United States. Int. J. Parasitol. 43:107-13.

Hiramoto, RM, Mayrbaurl-Borges, M, Galisteo, AJJr, Meireles, L R, Macre, MS, et al, 2001: Infectivity of cysts of the ME-49 Toxoplasma gondii strain in bovine milk and homemade cheese. Rev. Saude Publ. 35, 2:113-8.

Hossain, A, Bolbol, AS, Bakir, TM, Bashande, A, 1987: A serological survey of the prevalence of Toxoplasma gondii in slaughtered animals in Saudi Arabia. Ann. Trop. Med. Parasitol. 81, 1:69-70.

Hussein, MF, Almufarrej, SI, Aljumaah, RS, Al-Saiady, MY, EInabi, A, et al, 2011: Serological prevalence of Toxoplasma gondii and its association with abortion in sheep in Saudi Arabia. Acta Vet. 61, 4:405-14.

Hussein, MF, Bakkar, MN, Basmaeil, SM, Gar elNabi, A, 1988: Prevalence of toxoplasmosis in the Saudi Arabian camels (Camelus dromedarius). Vet. Parasitol. 28 1/2:175-8.

Iskandar, T, 1998: Pengisolasian Toxoplasma gondii dari otot diafragma seeker domba yang mengandung titer antibody tinggidan tanahtinja dari seekor kucing. IImu. Ternak. Vet. 3:111-6.

Kandil, OF, Gamal-Eddin, FM, Hosni, MA, El Dasouqi, IT, 1980: Toxoplasmosis and its effect on still birth and neonatal death. J. Egypt. Soc. Parasitol. 80, 1:27-33.

Khalil, MK, Elrayah, A, 2001: Seroprevalence of Toxoplasma gondii antibodies in farm animals (camels, cattle, and sheep) in Sudan. J. Med. Anim. Hlth. 3, 3:36-9.

Makki, SM, Abdel-Tawab AH, 2010:
Anti-Toxoplasma gondii antibodies among volunteer blood donors in Eastern Saudi Arabia. J. Egypt. Soc. Parasitol. 40, 2:401-12.

Mendonça, CE, Barros, SL, Guimarães, VA, Ferraudo, AS, Munhoz, A D, 2013: Prevalence and risk factors associated to ovine toxoplasmosis in northeastern Brazil. Rev. Bras. Parasitol. Vet. 22, 2:230-4.

Mirdha, BR, Samantaray, JC, Pandey, A, 1999: Seropositivity of Toxoplasma gondii in domestic animals. Indian J. Pub. Hlth. 43:91-2.

Mohammed, HI, 2011: Seroprevalence of Toxoplasma gondii infection in catrs, dogs and ruminant animals in AlAhasa area in Saudi Arabia. Res. J. Med. Sci. 5, 4: 190-2.

Mohammed, HI, Amin, TT, Balaha, MH, Moghannum, MS, 2010: Toxoplasmosis among the pregnant women attending a Saudi maternity hospital: Seroprevalence and possible risk factors. Ann. Trop. Med. Parasitol. 104, 6: 493-504.

Morsy, TA, EI Dasouqi, IT, 1973: Letter to the Editor. J. Trop. Med. Hyg. 76, 10: 256, London.

Morsy, TA, EI Dasouqi, IT, 1974: A case of toxoplasmosis manifesting as a febrile illness in Saudi Arabia. J. Pakis. Med. Ass. (Central) 24, 12:289.

Morsy, TA, El Dasouqi, ST, 1977: Toxoplasmin skin tests among some pilgrims in Saudi Arabia. J. Egypt. Soc. Parasitol. 7, 1: 81-3.

Morsy, TA, Sabry, AH, Habib, KS, Arafa, MA, el Bahrawy, AF, et al, 1994: Antibodies against toxoplasma in commensal rodents trapped in $\mathrm{Ri}$ - 
yadh Region, Saudi Arabia. J. Egypt. Soc. Parasitol. 24, 2:279-84.

Morsy, TA, El Bahrawy, AF, El Dakhil, MA, 2001: Ecto- and blood parasites affecting Meriones rex trapped in Najran, Saudi Arabia. J. Egypt. Soc. Parasitol. 31, 2:399-405.

Rifaat, MA, Morsy, TA, Sadek, MS M, Azab, ME, Safar, E.H, 1979: Incidence of toxoplasmosis among farm animals in North Coastal Zone of Egypt. J. Egypt. Soc. Parasitol. 9, 1: 193-7.

Saleem, AN, Fatohi, FA, 1993: Prevalence of Toxoplasma-link and Brucella antibodies in cattle with clinical and gynecological disturbances in Mosul, Iraq. Iraqi J. Vet. Sci. 6:48-52.

Sanad, MM, Al-Ghabban, AJ, 2007: Serological survey on toxoplasmosis among slaughtered sheep and goats in Tabouk, Saudi Arabia. J. Egypt. Soc. Parasitol. 37, 2:329-40.

Santos, TR, Costa, AJ, Toniollo, GH, Luvizotto, MC, Benetti, AH, 2009: Prevalence of anti-Toxoplasma gondii antibodies in dairy cattle, dogs and humans from the Jauru micro-region, Mato-Grosso state, Brazil. Vet. Parasitol. 161, 3/4:324-6.

Sarwat, MA, Ahmed, AB, Zamzami, OM, Fawzy, AFA, Morsy, TA, 1993: Toxoplasma gondii in Saudi blood donors: Serological study using 3 tests. J. Egypt. Soc. Parasitol. 23, 3:751-7.

Saudi Arabian Ministry of Agriculture, 2011: Agriculture Statistical Year Book No. 25, Saudi Arabia.

Shoura, MA, Morsy, T, El Dasouqui, IT, 1973: Toxoplasmin skin tests in
Riyadh, Saudi Arabia. J. Trop. Med. Hyg. 76, 10:254, London.

Skjerve E, Tharaldsen J, Waldeland H, Kapperud G, Nesbakken T, 1996: Antibodies to Toxoplasma gondii in Norwegian slaughtered sheep, pigs, and cattle. Bull. Scand. Soc. Parasitol. 6:11-7.

Soliman, MS, Morsy, TA, Farahat, MR, 1985: The toxic effects of pyrime-thamine in albino rats. J. Egypt. Soc. Parasitol.15, 1:353-64.

Tabbara, KF, 1990: Ocular toxoplasmosis. Int. Ophthalmol. 14, 5/6:349-51. van der Puije, WN, Bosompem, KM, Canacoo, EM, Wastling, JM, Akanmori, BD, 2000: The prevalence of anti-Toxoplasma gondii antibodies in the Ghanaian sheep and goats. Acta Trop. 76:21-6.

Tonkal, AMD, 2008: PCR versus ELISA in diagnosis of human toxoplasmosis in Jeddah, Saudi Arabia. J. Egypt. Soc. Parasitol. 38, 3:707-14

Turner, CB. Savya, D, 1990: Evidence of Toxoplasma gondii in an equine placenta. Vet. Rec., 127, 4:96

Voller, A, O'Neill, P, 1971: Immunofluorescence methods suitable for large scale application to malaria. Bull. WHO 45:524-9.

Yanaza, A, Kumari, P, 1994: Prevalence of Toxoplasma antibodies in blood donors in Al-Hassa. Ann. Saudi Med. J. 14:23-30.

Zaki, M, 1995: Seroprevalence of Toxoplasma gondii in domestic animals in Pakistan. J. Pak. Med. Assoc. 45:45. 